Imperial College for many years. Trained initially as a physicist under Sir Lawrence Bragg at the University of Manchester, he was attached by the Department of Scientific and Industrial Research in 1929 to the Imperial Geophysical Experimental Survey in Australia, where his interest in the use of physical methods of mineral exploration was first aroused. Two years later, on his return to England, he was enlisted by Prof. A. O. Rankine to help in setting up a school of geophysics within the Physics Department of the Imperial College, where it has continued to flourish progressively, especially during the past decade. His research activities have ranged far across the ever-widening field of geophysical prospecting, and he has enriched the literature by many pioneering contributions, notably on rock magnetism -a subject of profound academic and practical significance. Prof. Bruckshaw's diverse experience of geophysical surveys in many lands fits him well for the task of training students of geology and physics in the techniques of geophysical prospecting. At the same time, his intimate knowledge of field problems will enable him to direct research towards the twin goals of improved methods of subsurface exploration and of more reliable interpretations of geophysical anomalies. Under his guidance the Department of Applied Geophysics confidently expects to play an inoreasingly important part in providing skilled personnel to allay the growing demands of the mining and oil industries for help in the search for concealed mineral deposits at home and abroad.

Agriculture at Wye College, University of London: Prof. William Holmes

THE University of London chair in agriculture at Wye College, vacant since the appointment of Prof. M. McG. Cooper to the chair in King's College, University of Durham, is being filled by Dr. William Holmes, who comes from Kilbarchan in Renfrewshire, and is still in his early thirties. He was eduoated at the John Neilson Institution in Paisley and then took the degree course in agriculture of the University of Glasgow and the West of Scotland Agricultural College. He graduated in 1942 after winning several College medals and prizes, including the Weir of Courance Prize in advanced agriculture and the distinction of being the most successful final-year student; in the same year he was awarded the College and National Diplomas in Dairying. After becoming farm manager at the Hannah Dairy Research Institute, Dr. Holmes took a leading part in the work of the Institute which established the practicability of producing high yields of milk under war-time and other conditions of self-sufficiency in feeding-stuffs. This work had other important results, including a study of efficient utilization of pasture, and a convincing demonstration that unprecedentedly heavy applications of nitrogenous fertilizer to a ley could be economic provided the rest of the soil treatment was kept in balance. Dr. Holmes gained his doctorate for his share in these investigations, which have much interest for all concerned with the rational intensification of use of grassland.

\section{Institution of Mining and Metallurgy: Awards}

THE following awards have been made by the Institution of Mining and Metallurgy. Gold Medal of the Institution: Prof. W. R. Jones, past president of the Institution, in recognition of his services to the science of economic geology and to the Institution. Honorary Membership of the Institution: Sir Winston
Churchill ; Mr. G. A. Denny, in recognition of his distinguished services to the mining industry of the Union of South Africa, notably in the early development of Witwatersrand gold mines; and Dr. J. B. Tyrrell, in recognition of his work in the exploration and development of the mineral resources of Canada. Consolidated Gold Fields of South Africa, Limited, Premium of Forty Guineas : Mr. G. C. Norris, for his paper on some grinding tests with spheres and other shapes (Trans. Inst. Min. Metall., 63). Arthur Claudet Student's Prize : Dr. A. R. Barringer, for his paper on the preparation of polished sections of ores and mill products using diamond abrasives, and their quantitative study by point counting methods (Trans. Inst. Min. Metall., 63).

The Gold Medal which has been awarded to Prof. Jones is the highest honour the Institution can confer. Prof. Jones, who is seventy-five, was educated at the Imperial College of Science and Technology, London, and spent his early career abroad, first for four years in the Colonial Service as first assistant government geologist to the Federated Malay States, then in Burma during 1916-19 as general manager of High Speed Steel Alloys Mining Co., Ltd., and later as managing director of the Malayan China-Clay and Pottery Co. In 1926 he returned to the Imperial College to work in the Geology Department of the Royal School of Mines, being successively demonstrator, lecturer, reader and, in 1941, professor of mining geology. He retired in 1947, when he was made an emeritus professor, and in the following year he was made a C.B.E. An important feature of his work has been his investigations into the causes of silicosis and pneumoconiosis among miners in South Wales ; more recently he has been active as chairman of a working party appointed by the Government in 1946 to revive the china-clay industry in Great Britain, and as a member of the Mineral Resources Committee of the Ministry of Fuel and Power. Prof. Jones's connexion with the Institution dates back to 1916 when he became an associate member; for the past twenty years he has served continuously on the Council, holding the office of vice-president for the three sessions 1939-42 and president for the session $1947-48$.

\section{Television Service in Band III}

THE first report of the Postmaster General's Television Advisory Committee (1952) made it clear that the future development of television services in Britain must take place in the higher bands of radio frequencies, of which Band III (174-216 Mc./s.) must be the first to receive attention. The Independent Television Authority has now announced that commercial television will start in London on September 22 from a transmitting station now being built at Croydon, Surrey, and designed to operate in Channel 9 (191-196 Mc./s.). The British Broadcasting Corporation has also ordered transmitting equipment for the provision of an alternative television service in Band III, and has applied to the Postmaster General for an allocation of channels in the Band.

In order to assist the manufacturers of television aerials and receivers to operate on the new frequencies coming into use in Band III, arrangements have been made by the Radio Industry Council, in cooperation with the Independent Television Authority, for test transmissions to take place from a temporary station near Croydon. These experimental transmissions are now being made by Belling and Lee, Ltd., during $1030-1230 \mathrm{hr}$. and $1400-1600 \mathrm{hr}$. on 